УДК 343.121.5

DOI https: / / doi.org/ 10.32837 / yuv.v0i4.989

\author{
В. Кавецька,
}

аспірант кафедри кримінального процесу

Національного університету «Одеська юридична академія»

\title{
УЧАСТЬ ЗАКОННОГО ПРЕДСТАВНИКА НЕПОВНОЛІТНЬОГО У КРИМІНАЛЬНОМУ ПРОЦЕСІ
}

Однією з гарантій забезпечення прав і свобод людини у кримінальному процесі $€$ інститут представництва. Такий інститут особливо важливий для осіб, які в силу своїх фізичних чи розумових властивостей не здатні повною мірою захистити та реалізувати свої процесуальні права та обов'язки. Серед таких осіб найбільш незахищеними є неповнолітні особи, що і викликає актуальність дослідження у багатьох науковців.

Питанням участі та сутності законного представника неповнолітнього займались багато науковців, зокрема: Артеменко I.I., Куканова Г.В., Пожар В.Г., Романюк В.В., Самолюк В.В., Світлична Г.О. та інші. Разом із тим, постійний розвиток науки та кримінального процесуального законодавства вимагає деяких узагальнень та вироблення нових підходів та критеріїв.

Метою статті $€$ характеристика участі законного представника у кримінальному процесі України та аналіз змін до Кримінального процесуального кодексу України.

Неповнолітні особи, які потрапили у сферу кримінального процесу, у силу своїх вікових особливостей потребують посилення своєї правової захищеності, застосування до них особливих правил під час провадження й створення для них додаткових процесуальних гарантій. Однією $з$ форм правого захисту $€$ подвійне представництво інтересів неповнолітнього в суді - його законним представником і захисником (адвокатом). [1, с. 83]

Згідно 3 ч. 1 ст. 226 Кримінального процесуального кодексу України (далі - КПК України) допит малолітньої або неповнолітньої особи проводиться у присутності законного представника, педагога або психолога, а за необхідності - лікаря, а відповідно до ч. 1 ст. 354 КПК України допит малолітнього свідка і, за розсудом суду, неповнолітнього свідка проводиться в присутності законного представника, педагога чи психолога, а за необхідності - лікаря. [2]

Відповідно до ч. 1 ст. 488 КПК України батьки або інші законні представники неповнолітнього беруть участь у кримінальному провадженні за участю неповнолітнього підозрюваного чи обвинуваченого. Крім того, згідно 3 ч. 2 ст. 44 КПК України як законні представники можуть бути залучені батьки (усиновлювачі), а в разі їх відсутності - опікуни чи піклувальники особи, інші повнолітні близькі родичі чи члени сім’”, а також представники органів опіки і піклування, установ і організацій, під опікою чи піклуванням яких перебуває неповнолітній.

За КПК України 1960 року як законні представники могли бути залучені лише батьки, опікуни, піклувальники даної особи або представники тих установ і організацій, під опікою чи опікуванням яких вона перебуває. За чинним КПК України перелік таких осіб істотно розширений за рахунок надання можливості представляти неповнолітнього іншим повнолітнім близьким родичам чи членам сім’і. Такі зміни мають прогресивний ефект, адже вони спрямовані на посилення захисту і гарантування прав та свобод неповно- 
літнього підозрюваного, обвинуваченого.

Науковці не мають однакової думки щодо природи законного представництва у справах про злочини неповнолітніх, або потерпілих неповнолітніх. Оді вважають, що воно є лише різновидом представництва, інші наголошують на самостійності його статусу, крім того, існує думка, що поняття законного представника визначається не кримінально процесуальним, а сімейним законодавством. [3, с. 148]

Ми вважаємо, що законне представництво є міжгалузевим інститутом i визначається саме сімейним законодавством, хоч і має процесуальну направленість.

Відповідно до ч. 2 ст. 154 Сімейного кодексу України (далі - СК України) батьки мають право звертатися до суду, органів державної влади, органів місцевого самоврядування та громадських організацій за захистом прав та інтересів дитини, а також непрацездатних сина, дочки як їх законні представники без спеціальних на те повноважень.

Крім того, згідно з ч. 4 ст. 256-2 CK України прийомні батьки є законними представниками прийомних дітей і діють без спеціальних на те повноважень як опікуни або піклувальники.

Також ч. 4 ст. 256-6 СК України визначає, що батьки-вихователі є законними представниками дітей і діють без спеціальних на те повноважень як опікуни або піклувальники. [4]

3 аналізу положень Сімейного кодексу України виходить, що законне представництво має своєю основою саме сімейне законодавство, проте функціональне призначення законного представника направлене саме на процесуальну діяльність. Зокрема, на ряду 3 кримінальним процесуальним законодавством даний інститут використовується і в цивільному процесуальному. Наприклад, відповідно до ч. 1 ст. 60 Цивільного процесуального кодексу України (далі - ЦПК України) представником у суді може бути адвокат або законний представник. [5]
Згідно з наведеною нормою законні представники діють у цивільному судочинстві від імені та в інтересах осіб, які набули відповідного процесуального статусу, якщо вони з об'єктивних причин не можуть самостійно реалізувати надані їм процесуальні права i, як наслідок, ефективно захистити свої порушені, невизнані або оспорювані права, свободи та інтереси у суді. [6, с. 35]

Правова регламентація участі законних представників у цивільному судочинстві має імперативну форму. За наявності передбачених законом підстав їх участь у розгляді справи $€$ обов'язковою. У зв'язку з цим слід звернути увагу на певні особливості залучення до участі у справі законних представників неповнолітніх осіб віком від чотирнадцяти до вісімнадцяти років, а також осіб, цивільна дієздатність яких обмежена. Зазначені особи можуть самостійно здійснювати цивільні процесуальні права та виконувати свої обов'язки в суді у справах, що виникають з відносин, у яких вони особисто беруть участь, якщо інше не встановлено законом. [6, с. 37]

Як визначає В.Г. Пожар, законне представництво носить захисний щодо прав та законних інтересів цих осіб характер. Щодо взагалі представництва у кримінальному судочинстві, то вказується, що це окремий інститут, адже відповідні особи, наприклад, захисник та законний представник, не тільки виступають на захист прав неповнолітнього підозрюваного, а й здійснюють його представництво, те ж стосується і представника неповнолітнього потерпілого та свідка. Участь всіх цих представників має характер гарантії для осіб, яких вони представляють. Так, у літературі щодо представника відмічається, що це діяльність, уповноваженого в силу закону або договору на реалізацію та охорону прав і законних інтересів особи, яку він представляє, та на надання такій особі допомоги у реалізації іiі процесуальної функції та іiі суб'єктивних прав [7]. 


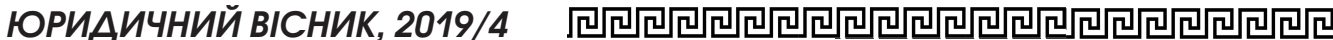

Існують різні точки зору стосовно визначення та функцій законного представника у процесі. Романюк В.В. зазначає, що як свідчить сама назва цього суб'єкта (законний представник), та що підтверджується аналізом чинного законодавства (зокрема, ст. 242 ЦК України, ст. 154 СК Україн), представник наділяється цим статусом саме в силу наявності між ним та особою, що представляється певного правового зв'язку (батьківства, встановлення опіки, тощо), на що і вказується в законі. Таким чином, якщо особа не вказана у нормативно-правовому акті, а саме законі України, як така, що має здійснювати обов'язки законного представництва, то залучати ii як законного представника неповнолітнього підозрюваного, обвинуваченого не можна. [8, с. 135]

В.В. Самолюк серед ознак, властивих виключно законному представництву, також виділяе таку, що законні представники отримують повноваження на представництво інтересів особи, яку вони представляють, не від неї самої, а на підставі закону. [9, с. 7]

Куканова Г.В. вважає, що участь законного представника у кримінальному процесі, з одного боку пов'язана з тим, що він повинен представляти законні інтереси неповнолітнього обвинуваченого, який із-за свого недостатнього розвитку, інтелекту, обмеженої процесуальної дієздатності потребує цього, з іншого, - його участь зумовлюється тим, що він має право здійснювати захист власних інтересів, які можуть бути порушені під час досудового та судового розслідування. У зв'язку з цим можна говорити про подвійний характер кримінально-процесуальної діяльності, яку виконує законний представник: одночасно захищаються інтереси та права неповнолітнього обвинуваченого та особисті права й інтереси представника. [3, с. 148]

Стосовно законодавчого визначення, то у Кримінальному процесуальному кодексі України стаття 44 має назву «Законний представник підозрю- ваного, обвинуваченого» та визначає, що якщо підозрюваним, обвинуваченим є неповнолітній або особа, визнана у встановленому законом порядку недієздатною чи обмежено дієздатною, до участі в процесуальній діі разом з ним залучається його законний представник.

Відповідно і ст. 59 КПК України називається «Законний представник потерпілого» і встановлює, що якщо потерпілим $є$ неповнолітня особа або особа, визнана в установленому законом порядку недієздатною чи обмежено дієздатною, до участі в процесуальній діï разом з нею залучається ії законний представник.

Проте, аналізуючи положення глави 3 КПК України, де передбачені учасники кримінального провадження ми не зустрічаємо законного представника свідка, що юридично унеможливлює віднесення його до учасників кримінального провадження.

Крім того п. 25 ч. 1 ст. 3 КПК України визначає, що учасниками кримінального провадження $€$ сторони кримінального провадження, потерпілий, його представник та законний представник, цивільний позивач, його представник та законний представник, цивільний відповідач та його представник, представник юридичної особи, щодо якої здійснюється провадження, третя особа, щодо майна якої вирішується питання про арешт, інша особа, права чи законні інтереси якої обмежуються під час досудового розслідування, особа, стосовно якої розглядається питання про видачу в іноземну державу (екстрадицію), заявник, свідок та його адвокат, понятий, заставодавець, перекладач, експерт, спеціаліст, представник персоналу органу пробаціï, секретар судового засідання, судовий розпорядник.

Але і тут не передбачено законного представника свідка, хоча адвокат свідка передбачений даною нормою та наявність законного представника свідка передбачено статтями 256 і 354 КПК України. 
На підставі вищевказаного пропонуємо доповнити Кримінальний процесуальний кодекс України статтею 67-1 «Законний представник свідка» у наступній редакції:

«1. Якщо свідком $€$ неповнолітня особа або особа, визнана в установленому законом порядку недієздатною чи обмежено дієздатною, до участі в процесуальній дії разом з нею залучається ii законний представник.

2. Як законні представники можуть бути залучені батьки (усиновлювачі), а в разі їх відсутності - опікуни чи піклувальники особи, інші повнолітні близькі родичі чи члени сім’і, а також представники органів опіки і піклування, установ і організацій, під опікою чи піклуванням яких перебуває неповнолітній, недієздатний чи обмежено дієздатний.

3. Законний представник користується процесуальними правами особи, інтереси якої він представляє, крім процесуальних прав, реалізація яких здійснюється безпосередньо підозрюваним, обвинуваченим і не може бути доручена представнику.

4. Питання участі законного представника потерпілого у кримінальному провадженні регулюється згідно з положеннями статті 44 цього Кодексу.»

Також пропонуємо викласти п. 25 ч. 1 ст. 3 КПК України в новій редакції 3 урахуванням законного представника свідка: «25) учасники кримінального провадження - сторони кримінального провадження, потерпілий, його представник та законний представник, цивільний позивач, його представник та законний представник, цивільний відповідач та його представник, представник юридичної особи, щодо якої здійснюється провадження, третя особа, щодо майна якої вирішується питання про арешт, інша особа, права чи законні інтереси якої обмежуються під час досудового розслідування, особа, стосовно якої розглядається питання про видачу в іноземну державу (екстрадицію), заявник, свідок, його законний представник та адвокат, понятий, заставодавець, перекладач, експерт, спеціаліст, представник персоналу органу пробації, секретар судового засідання, судовий розпорядник;»

У статmі дається загальна характеристика законного представника неповнолітнього у кримінальному прочесі України. У прочесі життя i розвитку неповнолітнього його відносини з батьками та іншими особами, які можуть бути наділені повноваженнями законних представників, складаються по-різному. Саме прихильність, взаєморозуміння, довіра неповнолітнього до законного представника є прямим шляхом до їх активної, спільної та узгодженої участі в проиесуальній діяльності, що, зрештою, сприяє забезпеченню прав $i$ захисту законних інтересів неповнолітныого. Якщо неповнолітній перебуває під опікою установ та організацій, також можна надати йому можливість вибору законного представника з числа адміністрації, праиівників иієї установи чи організації, педагогічному складу. Потерпілого неповнолітнього у кримінальному провадженні може представляти представник - особа, яка у кримінальному провадженні має право бути захисником. Що стосується представництва неповнолітніх потерпілих у кримінальному провадженні, то згідно зі статтею 59 КПК України, якщо потерпілим є неповнолітня особа, до участі в проиесуальній дї разом з нею залучається ї̈ законний представник. Процедура проведення dопиту неповнолітніх осіб заснована на загальних положеннях проведення допиту, регламентованих чинним кримінальним проиесуальним законодавством. Законний представник здійснюе лише представниитво інтересів неповнолітнього допитуваного. Завданням захисника є захист прав та інтересів неповнолітнього й за допомогою засобів захисту можливість виявити обставини, які пом'якшують чи виключа- 


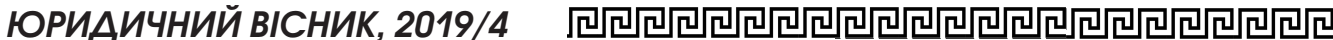

ють кримінальну відповідальність неповнолітнього. Проаналізовано думки щуодо природи законного представництва у справах за участю неповнолітніх як у кримінальному, так $і$ у ицвільному процесі. Визначено функції законного представника у кримінальному проиесі та запропоновано зміни до Кримінального процеесуального кодексу України.

Ключові слова: кримінальне процесуальне законодавство, неповнолітній, малолітній, представництво, законний представник.

\section{Kavetskaya V. PARTICIPATION OF A LEGAL REPRESENTATIVE OF A MINOR IN A CRIMINAL PROCESS}

The article gives a general description of the legal representative of a minor in the criminal process of Ukraine. In the course of the life and development of a minor, his or her relations with parents and other persons who may be vested with the powers of legal representatives differ in different ways. It is the commitment, understanding and trust of the minor to the legal representative that is a direct way to their active, joint and concerted participation in the legal process, which ultimately helps to secure the rights and protection of the legal interests of the minor. If the minor is in the care of institutions and organizations, you can also give him the opportunity to choose a legal representative from among the administration, employees of that institution or organization, teaching staff. The victim of a minor in criminal proceedings may be represented by a representative - a person who has the right to be a defender in criminal proceedings. With regard to the representation of juvenile victims in criminal proceedings, under Article 59 of the CPC of Ukraine, if the victim is a minor, his or her legal representative is involved with the proceedings. The procedure for conducting interrogation of minors is based on the general provisions of the interrogation, regulated by the current criminal procedural legislation. The legal representative only represents the interests of the minor interviewee. The task of the defense counsel is to protect the rights and interests of the minor and, through the means of protection, to identify circumstances that mitigate or exclude criminal liability of the minor. Opinions on the nature of legal representation in juvenile affairs in criminal and civil proceedings are analyzed. The functions of the legal representative in the criminal process were identified and amendments to the Criminal Procedure Code of Ukraine were proposed.

Key words: criminal procedural law, minor, minor, representation, legal representative.

\section{Література}

1. Артеменко I.I. Деякі аспекти залучення законного представника у кримінальних провадженнях щодо неповнолітніх / I.I. Артеменко / / Науковий вісник Ужгородського національного універсиmету. Серія Право. - 2015. - Bun. 35. T.3. - c. 82-85

2. Кримінальний процесуальний кодекс України: прийнятий 13 квітня 2012 року / / Відомості Верховної Ради України (ВВР). 2013. - № 9-10, № 11-12, № 13. cm.88.

3. Куканова Г.В. Право неповнолітнього учасника кримінального процесу на участь законного представника на досудових стадіях / Г. В. Куканова / / Європейські перспективи. - 2012. - № 4. - с. 147-151

4. Сімейний кодекс України: Закон України. // Відомості Верховної Ради України (ВВР). - 2002. - № 21. - cm. 135

5. Цивільний процесуальний кодекс України: Закон України. / / Відомості Верховної Ради України (ВВР). - 2004. № 40, 40-42. - cm. 492

6. Світлична Г.О. Законне представництво у цивільному судочинстві / Г.О. Світлична / / Вісник Верховного суду України. - 2013. - № 10 (158). - 34-41 c.

7. Пожар В. Г. Інститут представниитва в кримінальному судочинстві: дис. ... канд. юрид. наук : спец. : 12.00.09/ В. Г. Пожар ; Одес. нац. юрид. акад. Oдеca, 2010. - C. 7. 


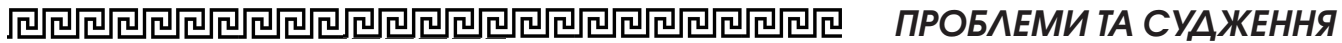

8. Романюк B.В. Удосконалення процесуального статусу законного представника неповнолітнього підозрюваного, обвинуваченого / В.В. Романюк / / Науковий вісник Ужгородського національного універcumeту. Серія Право. - 2013. - Bun. 23. T.3. - c. 134-137
9. Самолюк В. В. Законне представниитво у кримінальному прочесі України [Текст] : автореф. дис. ... канд. юрид. наук : 12.00 .09 «Кримінальний проиес та криміналістика; судова експертиза» / Василь Васильович Самолюк. - Київ : Б.в., 2005. - 20 c. 